\title{
SETTLEMENT MONITORING OF THE EARTH DAMS BY PERFORMANCE PERIODICAL TOPO-GEODETIC MEASUREMENTS
}

\begin{abstract}
Agapie (Mereuță) Ioana ${ }^{1}$, Luca Mihail ${ }^{2}$
Keywords: topographical marks, cadastral documentation, pillars, settlement, site layout plan

Abstract: The paper presents the current way of elaboration of the topographical and cadastral documentation needed in the process of tracking the behavior of hydrotechnical constructions such as earth dam. The studied area is represented by the accumulation of Pârcovaci located in the Deleni territorial administrative unit in Iași county. Using topo-geodetic measurements the magnitude of the vertical displacement of the studied construction were determined. The measurements were performed during the exploitation period of the dam, during 23 series of observations. Thus, there were highlighted the displacements of landmarks located on coping dam, downstream slope and outlet tower. Charts of evolution over time of vertical deformation have been made according to field observation. Also, the suface of the land corresponding to the whole of the accumulation of Pârcovaci was registered at Office of Cadastre and Real Estate Advertising Iași, through first registration documentation. This has made precise spatial delimitation of the set of lands and construction of studied area, and the whole land was recorded in the land book by assigning a unique cadastral number.
\end{abstract}

\section{Introduction}

The safety monitoring is very important in the operation and management of water resources and hydropower projects (Wang W. et al., 2018).

In accordance with national legislation, owners or administrators of dams, are required to obtain periodic authorization for safe operation. For category A and B dams it is issued for a period of maximum 7 years (Boariu C. et al., 2016).

Tracking behavior over time is fundamental for characterizing the structural behavior of earth dams and for identifying potential damages (Ricardo B. et al., 2018).

${ }^{1} \mathrm{PhD}$ student, Doctoral School, Technical University „Gh. Asachi” of Iasi, Romania, ioanaagapie@yahoo.com

${ }^{2} \mathrm{PhD}$ eng. professor, Technical University “Gheorghe Asachi” of Iasi, Romania, mluca2004@yahoo.com 
Monitoring of massive earth mainly involves the observation of the evolution of vertical deformation. Engineering, especially civil engineering, depends very much on surveyors (Dumitrache C.G., 2018).

Achieving hydro-technical objectives to the earth dams requires the use of a complex of technical and financial documentation. Different studies are used to design technical projects such as: topographic studies, geotechnical studies, hydrological studies, hydraulic studies, climate studies, hydro-geological studies, etc. In all these studies, the topographic documentation is the most important based on topographic measurements (Luca M., et al., 2017).

Earth dams play a key role in supporting economies (Ruijie Xi et al.,2018). The purpose of the paper is to analyze topographic data taken over several series of observations, interpreting the results of the measurement made in order to determine the slumps and technical analysis of existing cadastral documentation.

\section{Material and research method}

Research material is the Pârcovaci earth dam which was built between 19781984 and put into operation in 1984.

The accumulation of Pârcovaci is situated in the upper basin of the Bahlui river, on the territory of Deleni commune, located at $10 \mathrm{~km}$ from the town of Hârlău, Iași county (Fig. 1). Legally, the objective studied is part of the public domain of the State and is managed by A. N. Apele Române, Prut-Bârlad Water Basin Administration.

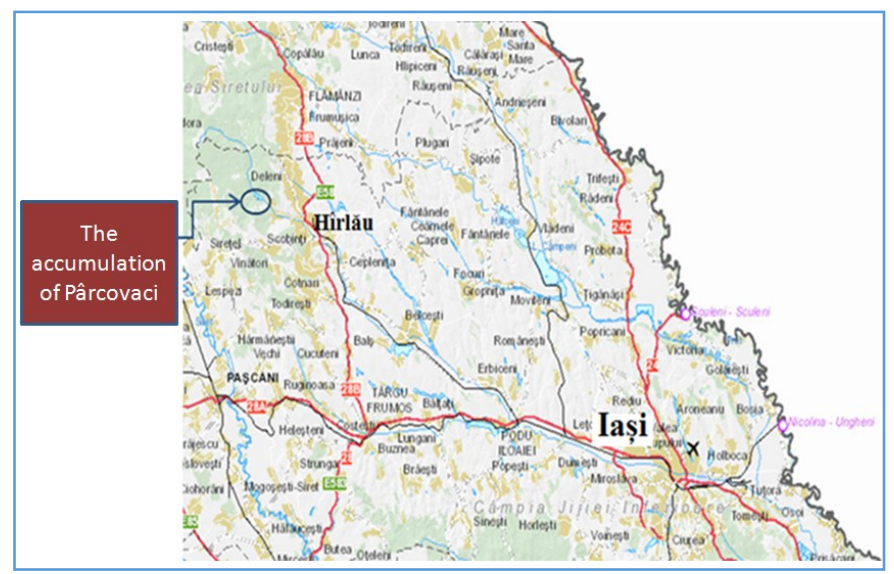

Fig.1. Representation of the Northeast Region of Romania with location of Pârcovaci dam 
The accumulation of Pârcovaci is a complex hydrotechnical arrangement, consisting of a series of components characteristic of earth dams. To track the evolution of vertical deformations, 17 vertical leveling landmarks were mounted on the dam body, 4 stamp marks on the access passage, a mark on the outlet tower and 6 pillars located outside the area of influence of the dam (fig. 2).

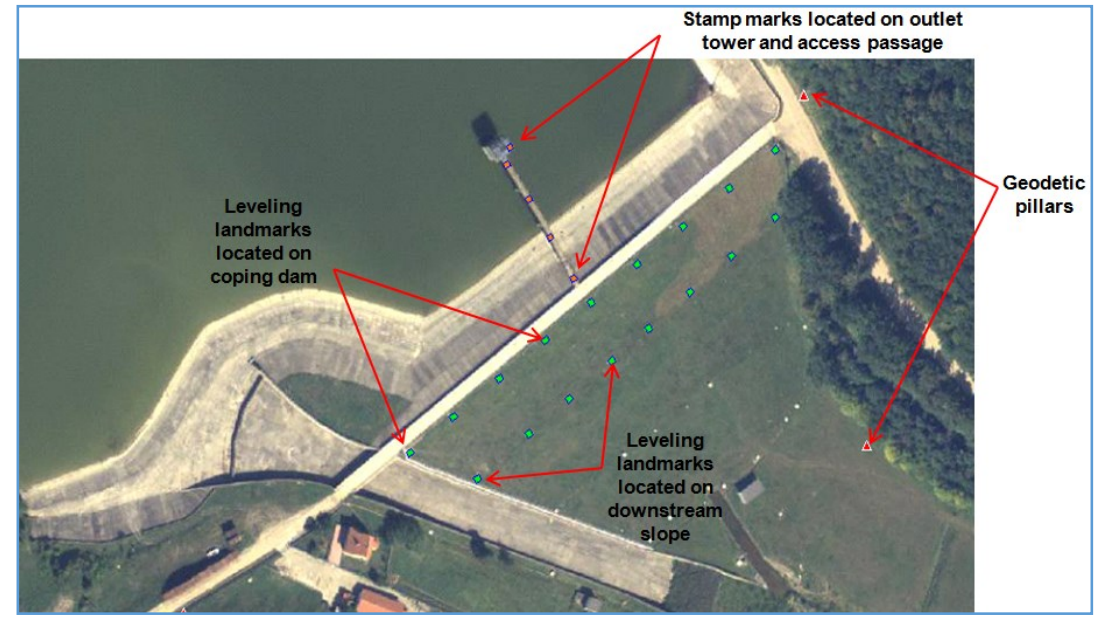

Fig. 2. Orthophotoplan with representation of leveling landmarks, stamp marks and pillars

Leveling landmarks located on the dam body is distributed accordingly:

- 9 leveling landmarks located on the coping dam (fig. 3.a);

- 8 leveling landmarks located on downstream slope (fig. 3.b);

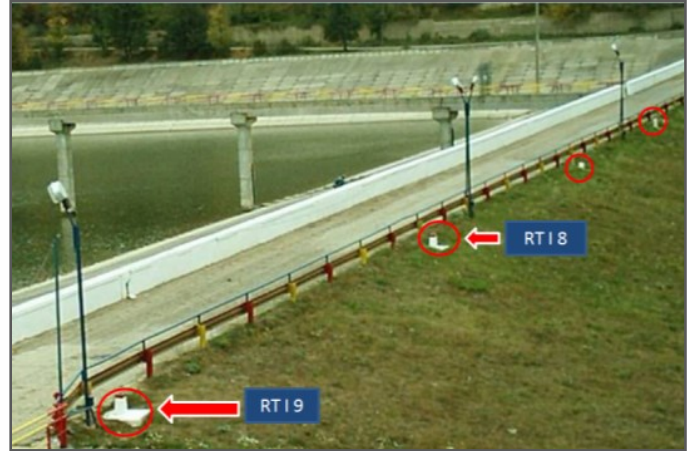

a.

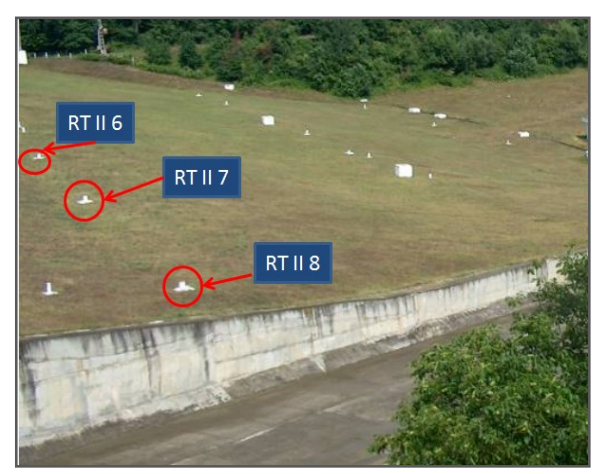

b.

Fig. 3. Location of laveling landmarks: $a-$ on coping dam; $b$ - on downstream slope(Source: A.B.A. Prut - Bârlad) 
The research methodology consists of:

- Cartographic analysis of the studied objective by fitting on geodetic trapezes;

- Analysis of topographic measurements drawn periodically to track the evolution of vertical deformation over time;

- Analyzing and interpreting the location plan of leveling landmarks;

- Analysis of the existing cadastral documentation and the Land Book extract;

In order to track the evolution of vertical deformation, 23 series of topographic measurements were performed between 14 October 1994 and 30 October 2017. The hole surface of the accumulation of Pârcovaci was registered at the Office of Cadastre and Real Estate Advertising Iasi, on 20.12.2007.

\section{Results and discussions - Case study}

The Pârcovaci dam was classified in Class II, category B, of great importance. The main functions that this hydrotechnical objective fulfills are: the water supply of the Hârlău town and the flood protection of downstream localities (Hârlău, Scobinți, Ceplenița and Cotnari). The monitoring of the hydro-technical objective described is a particularly important activity. This consist in systematically performing topographical measurements, recording the data and interpreting them as graphs and reports.

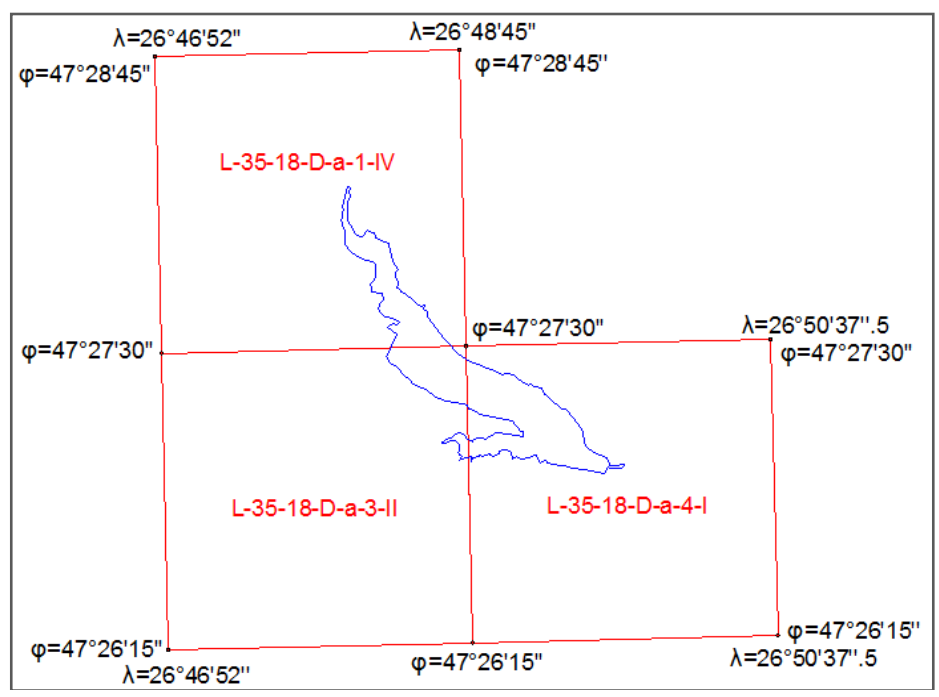

Fig. 4. Representation on the geodetic trapezes of the studied object 
Settlement monitoring of the earth dams by performance periodical topo-geodetic measurements 103

From cartographic point of view, Pârcovaci complex falls on three geodetic trapezes at a scale of 1:5000, with nomenclatures: L-35-18-D-a-1-IV, L-35-18-D-a3-II, L-35-18-D-a-4-I (Fig. 4).

Geographical coordinates of trapezoidal corners $(\varphi, \lambda)$ were determined by converting the stereographic coordinates $(\mathrm{X}, \mathrm{Y})$.

Case study developed for the Pârcovaci hydro-technical complex, from Iași county, indicates the need for periodic updating of topographic measurements.

Between 1994 and 2017, 23 series of observation were made. They were monitored 9 leveling landmarks located on the coping dam and 8 leveling landmarks located on downstream slope of the dam. Starting with 2007 observations were made also on the three landmarks mounted on the access passage and a landmark on the outlet tower (Bălan I. et al., 2018).

Time tracking of vertical movements was achieved by the classical method of terrestrial measurements. The first series of observation were performed using classic instruments, such as theodolites and optical levels, and in recent years, using high precision geotagging tools (digital surveyor's level, total stations and GPS systems).

Table 1. The maximum and minimum values of slump on coping dam, recorded during the last three observation cycles

\begin{tabular}{|c|c|c|c|c|}
\hline \multirow{2}{*}{ Date } & \multicolumn{2}{|c|}{ Relative slump } & \multicolumn{2}{c|}{ Total slump } \\
\cline { 2 - 5 } & $\begin{array}{c}\text { Maximum } \\
\text { values (mm) }\end{array}$ & $\begin{array}{c}\text { Minimum } \\
\text { values (mm) }\end{array}$ & $\begin{array}{c}\text { Maximum } \\
\text { values (mm) }\end{array}$ & $\begin{array}{c}\text { Minimum } \\
\text { values (mm) }\end{array}$ \\
\hline 30.09 .2015 & $-7,0$ & $+5,2$ & $-125,8$ & $-23,8$ \\
& RTI6 & RTI1 & RTI6 & RTI1 \\
\hline \multirow{2}{*}{20.05 .2016} & $-10,9$ & 0,0 & $-126,8$ & $-31,6$ \\
& RTI3 & RTI4 & RTI6 & RTI1 \\
\hline 30.10 .2017 & $+5,1$ & $-0,1$ & $-126,9$ & $-26,5$ \\
& RTI1 & RTI6 & RTI6 & RTI1 \\
\hline
\end{tabular}

Source: A.B.A. Prut-Bârlad

After analyzing the measurements made during the last three years of monitoring, the following maximum and minimum slump values were found:

- For landmarks located on coping dam (Table 1);

- For landmarks located on downstream slope of the dam (Table 2);

- For landmarks located on dam tower and passage access (Table 3); 
Vertical displacements have been analyzed based on field measurements for landmarks sit on coping dam, downstream slope, passage access and dam tower (fig. 5, fig. 6 și fig. 7).

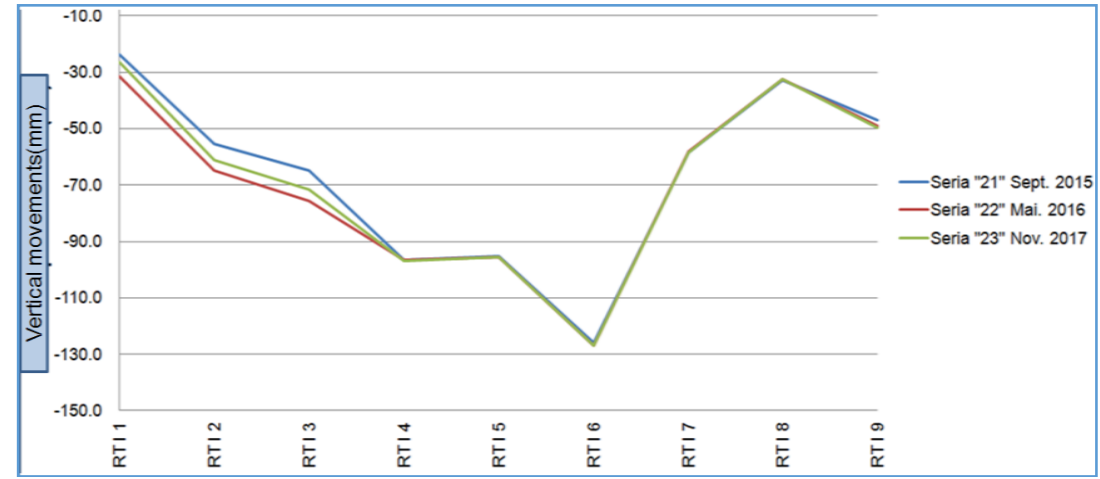

Fig. 5. The evolution of slump on coping dam recorded for the last series of observation

In the measurement process were recorded with RTI, landmarks located on coping dam and with RTII, landmarks located on downstream slope. They were numbered with arabic numerals, from 1-9, the marks located on coping dam and from 1-8 the marks located on downstream slope. Pillars located on the passage access were recorded with P1, P2, P3, P4 and the pillar located on dam tower was recorded with $\mathrm{T} 1$.

Table 2. The maximum and minimum values of slump on downstream face of the dam, recorded during the last three observation cycles

\begin{tabular}{|c|c|c|c|c|}
\hline \multirow{2}{*}{ Date } & \multicolumn{2}{|c|}{ Relative slump } & \multicolumn{2}{c|}{ Total slump } \\
\cline { 2 - 5 } & $\begin{array}{c}\text { Maximum } \\
\text { values (mm) }\end{array}$ & $\begin{array}{c}\text { Minimum } \\
\text { values (mm) }\end{array}$ & $\begin{array}{c}\text { Maximum } \\
\text { values (mm) }\end{array}$ & $\begin{array}{c}\text { Minimum } \\
\text { values (mm) }\end{array}$ \\
\hline \multirow{2}{*}{30.09 .2015} & $-5,2$ & $+3,5$ & $-80,6$ & $-15,1$ \\
& RTII4 & RTII8 & RTII4 & RTII8 \\
\hline \multirow{2}{*}{20.05 .2016} & $-3,7$ & 0,0 & $-84,3$ & $-17,7$ \\
& RTII4 & RTII1 & RTII4 & RTII8 \\
\hline \multirow{2}{*}{30.10 .2017} & $-1,0$ & $-0,1$ & $-85,0$ & $-18,7$ \\
& RTII2 & RTII1 & RTII4 & RTII8 \\
\hline
\end{tabular}

Source: A.B.A. Prut-Bârlad 
Analyzing the values of the vertical displacements during the last three years of monitoring the dam behavior, it can be seen that the highest value of compaction, in relation to the 0 measurement cycle, was recorded for the topographical mark RTI6, on the coping dam, with a value of $126.9 \mathrm{~mm}$ (table 1, fig. 1). The area least exposed to the compaction process is the dam tower where the $\mathrm{T} 1$ topographical mark has a minimum compression value of $3.7 \mathrm{~mm}$ (Table 3 , fig. 3).

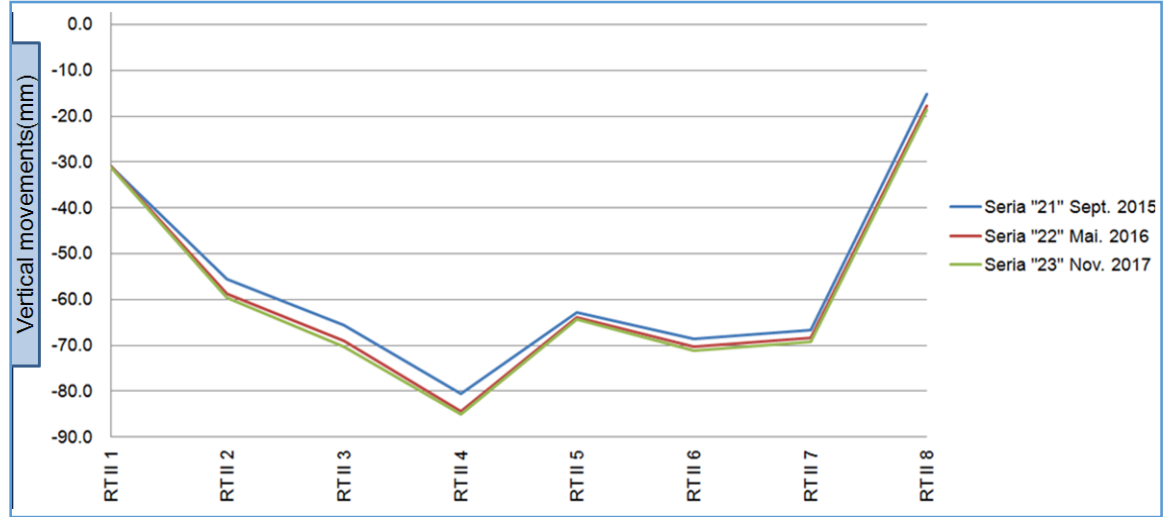

Fig. 6. The evolution of slump on downstream face of the dam recorded for the last series of observation

Table 3. The maximum and minimum values of slump on outlet tower and access passage, recorded during the last three observation cycles

\begin{tabular}{|c|c|c|c|c|}
\hline \multirow{2}{*}{ Date } & \multicolumn{2}{|c|}{ Relative slump } & \multicolumn{2}{c|}{ Total slump } \\
\cline { 2 - 5 } & $\begin{array}{c}\text { Maximum } \\
\text { values (mm) }\end{array}$ & $\begin{array}{c}\text { Minimum } \\
\text { values (mm) }\end{array}$ & $\begin{array}{c}\text { Maximum } \\
\text { values (mm) }\end{array}$ & $\begin{array}{c}\text { Minimum } \\
\text { values (mm) }\end{array}$ \\
\hline \multirow{2}{*}{30.09 .2015} & $-3,7$ & $+1,3$ & $-16,4$ & $-3,9$ \\
& $\mathrm{P} 2$ & $\mathrm{~T} 1$ & $\mathrm{P} 1$ & $\mathrm{P} 4$ \\
\hline \multirow{2}{*}{20.05 .2016} & $-1,6$ & $-0,5$ & $-18,0$ & $-3,7$ \\
& $\mathrm{P} 1$ & $\mathrm{P} 3$ & $\mathrm{P} 1$ & $\mathrm{~T} 1$ \\
\hline 30.10 .2017 & $-0,9$ & $-0,1$ & $-18,9$ & $-4,5$ \\
& $\mathrm{P} 1$ & $\mathrm{P} 2, \mathrm{P} 4$ & $\mathrm{P} 1$ & $\mathrm{~T} 1$ \\
\hline
\end{tabular}

Source: A.B.A. Prut-Bârlad 
As a result of the analysis we can see a normal evolution of the studied dam, without noticeable special events or atypical behaviors. Tracking monitoring will continue in the coming years, throughout the lifetime of the dam. Measurements are made annually or after any natural accidental phenomenon (earthquakes, slopes).

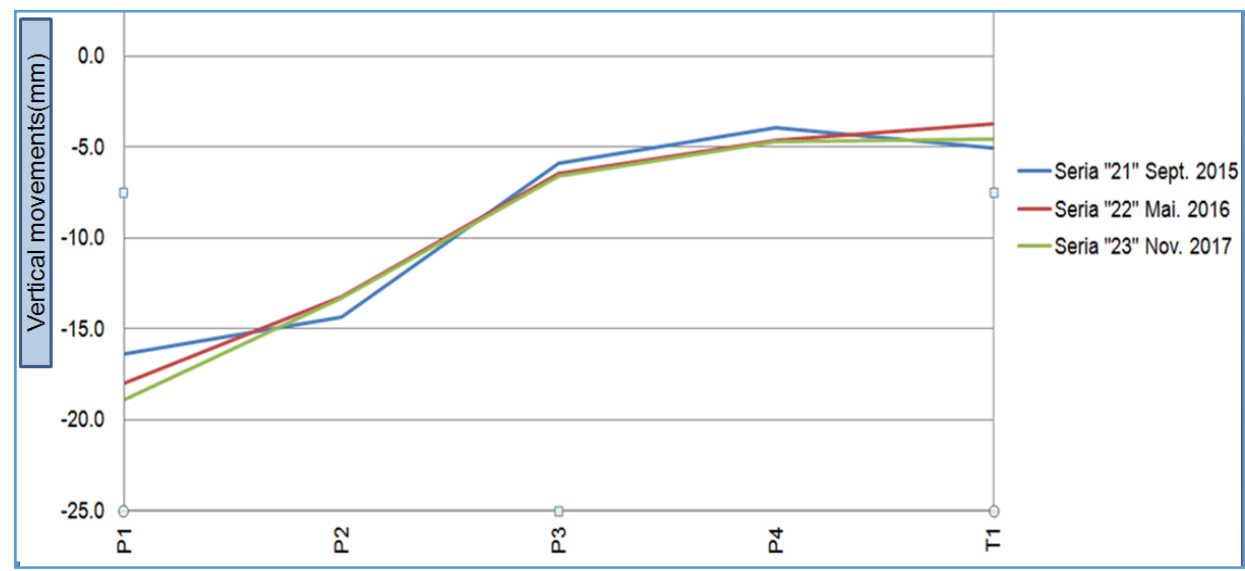

Fig. 7. The evolution of slump on outlet tower and access passage recorded for the last series of observation

From documentary analysis, nationally, it can be observed that the monitoring of the dams is done by classical topo-geodesic tracking methods, using high precision ground measurement instruments. In Romania, the process of implementing new technologies of the GPS type, total station and digital level, it took place with a certain delay, but it can be considered completed in a first phase (Boș et al., 2015).

Since any project for the rehabilitation or improvement of the Pârcovaci hydro-technical complex depends on the positioning of this objective in space, in 2007 the cadastral documentation was drawn and registered in the land book. The hole complex was measured on its property limits, respecting the boundaries of neighboring lands. As a result of the measurements, a total area of $945080,80 \mathrm{mp}$ was determined. A number of 14 categories of land use have been identified and delimited for Pârcovaci hydro-technical complex and 6 related buildings were located.

These are described in detail, with related surfaces, in the land register for information, emitted in 2013 (fig. 8). In the extract it is noted that, at that time, the Pârcovaci hydro-technical complex did not record the geometry of the area in the 
information system. Starting with 2016, in ANCPI, the new information system Eterra version 3 was implemented, which allows permanent updating of both textual data and graphical data. Thus, the geometry of the studied object was introduced and updated in the Eterra 3 online database (fig. 9). Access and management in the online environment, offers the possibility of authorized persons to interrogate data and update text or graphical information related to the lands that are part of the integrated cadastre and land registry system.

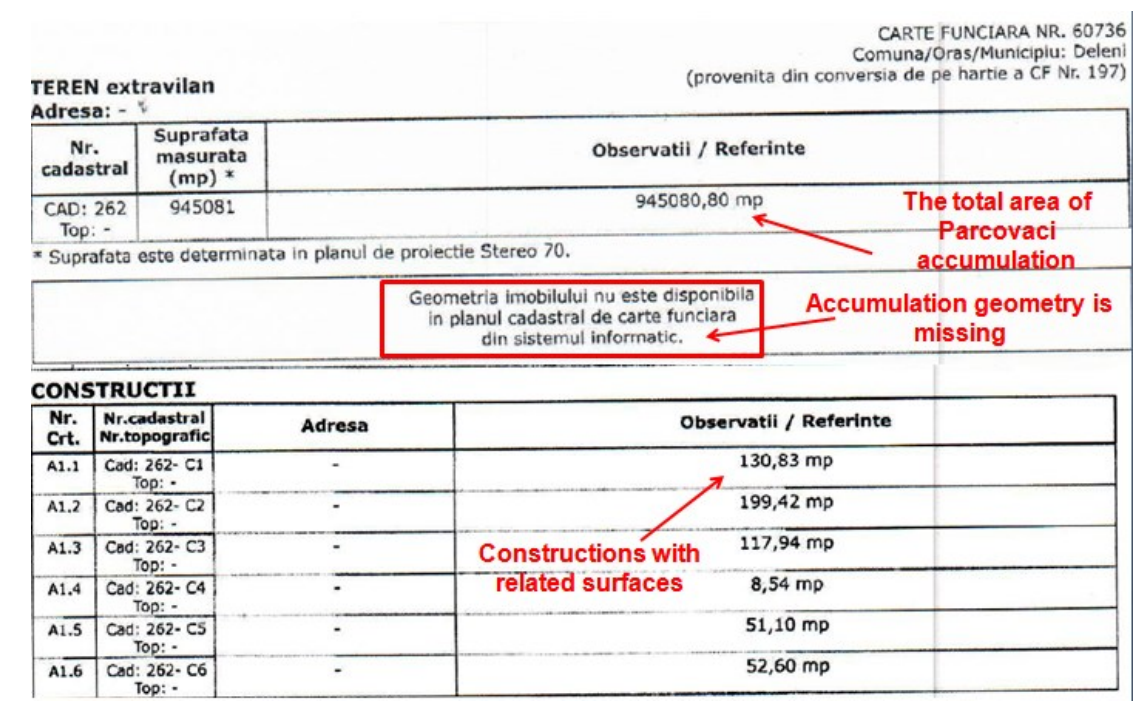

Fig. 8. Representing in the land book extract the total area of accumulation and the construction surfaces of the Pârcovaci hydro-technical complex

The Eterra 3 information system offers an interactive viewing mode. This system allows users to verify the accuaracy of measurements, by checking the boundaries of the neighboring lands but also by viewing the orthophotoplan. The Eterra 3 system offers many benefits to users such as citizens, the business environment and the administration, including:

- Direct (online) consultation of cadastral-legal records.

- Unified access to data from multiple institution.

- Semi-automatic updating and real-time transmission of cadastral-legal records between institution.

- The ability to automatically provide information or alert information via email or mobile phone messages. 
- Ensures integrity and accuracy of data regarding individuals, legal, addresses.

- Provides real-time access to analytics and real estate data.

With Eterra 3 Information System, specialists from the Prut-Bârlad Water Basin Administration can query data through the export option or request updating them.

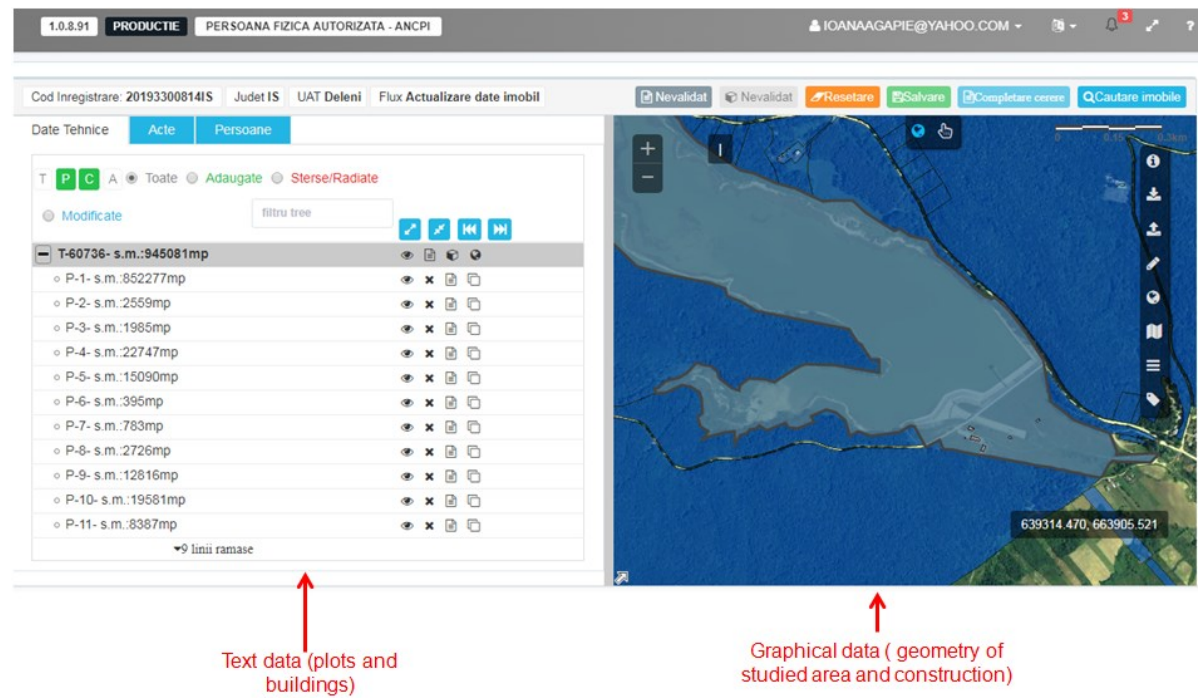

Fig. 9. Representation in the Eterra 3 information system of graphical and textual data corresponding to the Pârcovaci hydro-technical complex

\section{Conclusions}

1. Periodic monitoring of vertical movements to earth dams it has a particular importance, because atypical behaviors of the observed masses can be detected and any accidents caused by compaction can be prevented.

2. From measurements made between 2015-2017, was highlighted a normal behavior of the Pârcovaci dam. Earth measurement method with high precision instrument is the classic method but which allows the determination of compactions with millimeter precision.

3. In the future, within the following observation cycles, new methods for tracking vertical movements can be implemented, with the help of modern measurement technologies. 
4. Preparation of topographical and cadastral documentation has a particularly important role in the realization of future rehabilitation projects and the development of the studied objective.

5. Registration of the whole accumulation in the integrated cadastre and land registry system allows you to view and update your information in real time, in the online environment, through the GIS application, Eterra 3.

\section{References}

1. Bălan I., (2018) Acumulare Pârcovaci. Regulament de exploatare, Administrația Națională "Apele Române" Administrația Bazinală de Apă Prut Bârlad.

2. Boariu C., (2016) Safety assurance on existing dams. Case study - Sârca dam, Buletinul Institutului Politehnic din Iași, vol. 62 (66), nr.3-4, secția Hidrotehnică, pp. 59-66.

3. Boș N., Iacobescu O., Boș N.C., (2015) Topografie Digitală , editura C.H. Beck, București, pp. 130-331.

4. Dumitrache C. G., (2018) Topography and Cadastral Applications, International Journal of Recent Technology and Engineering, volume 7, issue 2, pp. 7-10.

5. Luca M., Luca A.L., Toma D., Tămășanu F., (2017) Update of the topographic parameters of the structural elements to the pipes network, Revcad, volume 23, "1 Decembrie 1918" University, Alba Iulia, pp. 137-144.

6. Riccardo B., Noemi Emanuela C., Carlo L. G., Pinto L., Tornatore V., (2018) Estimating and comparing dam deformation using classical and GNSS techniques, Sensors, volume 18, nr. 756, pp.1-11. https://doi.org/10.3390/s18030756

7. Ruijie X., Xiaohui Z., Weiping J., Qusen C., (2018) Simultaneous estimation of dam displacement and reservoir level variation from GPS measurement, Elsevier, measurement 122, pp. 247-256. https://doi.org/10.1016/j.measurement.2018.03.036

8. Wang W., Chen Z., Li X., (2018) The arrangement of deformation monitoring project and analysis of monitoring data of a hydropower engineering safety monitoring system, ICEESE 2017, IOP Conf. Series: Earth and Environmental Science, nr. 128, pp. 1-8. doi :10.1088/1755-1315/128/1/012006

9. NP087-2003 - Normativ de urmărirea comportării construcțiilor hidrotehnice.

10. STAS 4294-73 - mărci pentru nivelment și triangulație geodezică - reperele de adâncime și de suprafață.

11. STAS 788390 - Construcții hidrotehnice. Supravegherea comportării în timp.

12. STAS 2745 - 90 - UCTC prin măsurători topometrice.

13. Legea 7/1996 - Legea cadastrului și a publicității imobiliare.

14. http://www.ocpi-ms.ro/e-Terra3.html.

C) 2020 by the authors. Licensee UAIC, Iasi, Romania. This article is an open access article distributed under the terms and conditions of the Creative Commons Attribution (CC BY-NC-ND) license (https:// creativecommons.org/licenses/by-nc-nd/4.0). 